STUDII

\title{
O VIZIUNE GLOBALĂ ASUPRA SITUAȚIEI PATRIMONIALE A SOȚULUI SUPRAVIETUUITOR ÎN DREPTUL ROMAN
}

DOI: 10.24193/SUBBiur.64(2019).1.2

Published Online: 2019-03-18

\section{Alina-Emilia Ciortea*}

Rezumat: În prezentul studiu am efectuat o analiză a reglementărilor în materia drepturilor succesorale ale soțului supraviețuitor din vechiul dreptul roman, dreptul pretorian și dreptul imperial. Astfel, am pornit în cercetare de la dispozițiile Legii celor XII table, din perioada vechiului drept roman și am străbătut mai multe secole până la codificarea împăratului Iustinian din secolul al VI-lea p. Chr. Accentul s-a pus preponderent pe evidențierea contextului istoric și sociologic în care soțul supraviețuitor a beneficiat de un drept de uzufruct ca urmare a deschiderii moștenirii, respectiv a încetării regimului matrimonial aplicabil uniunii conjugale.

Am studiat, în raport cu fiecare perioadă istorică relevantă, condițiile care sunt necesar a fi întrunite pentru ca uzufructul legal să se nască în patrimoniul soțului supraviețuitor. Totuși, din motive ce țin de cursivitatea analizei am făcut precizări cu privire la dreptul de moștenire al soțului supraviețuitor, dar și a succesorilor legali, în general.

* Alina-Emilia CiorTEa este student-doctorand la Universitatea „Babeş-Bolyai”, Facultatea de Drept din Cluj-Napoca, LL.M. in Comparative Law la Louisiana State University, Louisiana, Statele Unite ale Americii, avocat definitiv, membru al Baroului Cluj. Poate fi contactată la adresa de e-mail: alina.emilia.ciortea@gmail.com. 
Cuvinte cheie: soț supraviețuitor, drept de uzufruct, succesiune, moștenire, vechiul drept roman, dreptul pretorian, dreptul imperial, succesiune legală.

\title{
AN OVERVIEW OF SURVIVING SPOUSE'S FINANCIAL POSITION IN ROMAN LAW
}

\begin{abstract}
We conducted an analysis of the succession rights of surviving spouse the succession rights of surviving spouse in Ancient Roman Law, Pretorian Law and Imperial Roman Law. Thus, we have done research starting from the Law of Twelve Tables, dating from Ancient Roman Law and we have come across the years until Iustinian's Codification, in the 6th century BC. The focus is mainly on the historical and sociological context in which the surviving spouse had a usufruct over the decedent's share which was generated by the transmission of the estate of the deceased and the termination of the matrimonial regime.

Concerning every relevant historical period, we have studied the mandatory conditions that needed to be fulfilled in order to provide a legal usufruct to the surviving spouse. However, to enhance the fluency of the study, we have made some remarks related to the rights of the surviving spouse and other heirs, in general.

Keywords: surviving spouse, usufruct, succession, heritage, Ancient Roman Law, Pretorian Roman Law, Imperial Roman Law, intestate succession.
\end{abstract}

\section{Introducere}

În cuprinsul acestui articol ne vom ocupa de situația soțului supraviețuitor în perioada dreptului roman, defalcând analiza pe cele trei momente istorice importante: vechiul drept roman, dreptul pretorian și dreptul imperial. În această ultimă secțiune vom acorda atenție sporită legislației lui Iustinian. 
În cadrul lucrării, vom analiza atât regulile de drept succesoral din cadrul moștenirii legale, cât și dispoziții aparținând altor ramuri de drept, dar care au efecte succesorale directe sau indirecte, cum sunt, de pildă, regimurile matrimoniale, constituirea zestrei, a contra-zestrei etc.

Ne propunem, de asemenea, să cercetăm consecințele juridice declanșate de moartea fiecăruia dintre cei doi soți, pentru a puncta diferențele de substanță dintre aceste evenimente.

\section{Vechiul drept roman}

Fizionomia dreptului de moștenire al soțului supraviețuitor și evoluția acestuia de-a lungul timpului se află într-o legătură indisolubilă cu instituția juridică a căsătoriei, precum și cu celula de bază a societății, familia. ${ }^{1}$

Este important de menționat faptul că familia patriarhală romană era centrată asupra personajului principal: șeful de familie (pater familias), figură care exercita o putere discreționară asupra persoanelor și asupra bunurilor pe care le avea sub putere. ${ }^{2}$ În acest sens, jurisconsultul Ulpian afirmă pater autem familias appellatur qui in domo dominium habet (se numește șef de familie cel care deține puterea în casă). 3 Așadar, pater familias are, în sânul familiei, un rol asemănător cu cel al unui rege. ${ }^{4}$ Acesta este, în

\footnotetext{
${ }^{1}$ Pentru a elucida parcursul evolutiv al dreptului de moștenire al soțului supraviețuitor, vom analiza construcția familiei romane, atât din perspectivă religioasă, cât și dintr-una civilă.

${ }^{2}$ Dan OANCEA, Introducere în dreptul roman, ed. C.H. Beck, București, 2009, p. 82.

${ }^{3}$ Nov. 162.2.

${ }^{4} \mathrm{Cu}$ toate acestea, au fost exprimate și susțineri potrivit cărora autoritatea supremă în familie nu aparținea lui pater familias, ci religiei casnice, adică acelui zeu pe care romanii îl numeau Lar Familiae Pater. Fustel DE Coulanges, Cetatea antică, ed. Librăriei SOCEC\&Co, București, 1929, p. 92.
} 
acelaşi timp, titularul întregului patrimoniu familial, preot al cultului familial şi judecător al celor pe care îi are în putere (domesticus magistratus). Prerogativele şefului de familie se întind, în această epocă, până la dreptul de viață și de moarte asupra persoanelor aflate sub puterea sa (ius vitae necisque)5.

Din perspectivă atribuțiilor religioase, pater familias este cel în drept să aprindă focul sacru, să înjunghie victima, să pronunțe formule religioase care sunt menite să confere familiei protecția zeilor etc. ${ }^{6}$

Se pune întrebare: cine va săvârși actele religioase ale cultului familiei după moartea şefului de familie? Conform regulii, ritualul religios este condus de către descendenții de sex masculin, aflați sub puterea lui pater familias, la data deschiderii moștenirii.7 Cutuma locală stabilea că primul fiu născut va succeda în atribuțiile religioase ale șefului de familie, la momentul decesului acestuia din urmă. ${ }^{8}$ Așadar, rezultă că fiicele sau soția (indiferent de felul căsătoriei) nu-i vor putea succeda defunctului în ceea ce privește oficierea cultului religios al familiei.

În privința fiicei, s-a arătat că aceasta nu este aptă să continue religia părintească, întrucât la momentul la care aceasta încheie o căsătorie ${ }^{9}$ ea renunță implicit la cultul tatălui său și adoptă religia casnică a soțului, din

\footnotetext{
${ }^{5}$ Legea celor XII Table IV.2.

${ }^{6}$ Fustel De Coulanges, op.cit., 1929, p. 93.

${ }^{7}$ Idem, p. 77.

${ }^{8}$ În situația în care cel mai în vârstă dintre fii este predecedat sau nedemn de a săvârși ritualul religios, un al descendent de sex masculin (fie rudă de sânge sau agnatică) va prelua această responsabilitate. C. M. BRUNE, The Origin and History of Succession in Roman Law, Law Magazin and Review: A Quarterly Review of Jurisprudence nr. 36/2011, p. 433.

9 Desigur, este vorba despre căsătoria cum manu, deoarece aceasta era singura formă cunoscută la vremea respectivă.
} 
noua familie. ${ }^{10}$ Așadar, calitatea ei de viitoare moștenitoare în familia de origine este condiționată de necontractarea unei căsătorii cum manu, deci implicit de situarea ei sub aceeaşi putere părintească (patria potestas).

Odată intrată în noua familie, se observă că, în privința actelor religioase, soția nu se afla pe o poziție de egalitate cu pater familias. ${ }^{11}$ Astfel, în viața romană de familie, soția este văzută ca un ajutor al soțului ei și nu ca un membru al familiei cu autoritate sau care poate oficia ceremonia religioasă. ${ }^{12}$ În acest sens, în doctrină s-a susținut că însuşi scopul căsătoriei, în perioada primitivă, a fost de a crește fii pentru ca aceștia din urmă să poate perpetua cultul familial religios, deci să poată fi succesori ai șefului de familie. ${ }^{13}$ Căsătorită după ritualurile sacre, soțiai ${ }^{14}$ devine asociată a cultului, putând asista la ceremonial, dar întrucât nu descinde din strămoşii familiei soțului, nu poate fi niciodată conducătoarea cultului casnic. ${ }^{15}$ Prin urmare, soția căsătorită cum manu, în această perioadă, nu are niciun fel de atribuții religioase care să îi dea autoritate în cămin.

În cele ce urmează, vom vedea care sunt consecințele în plan succesoral ale excluderii femeii de la oficierea cultului religios.

În epoca veche, elementul esențial al succesiunii îl reprezintă transmiterea atribuțiilor religioase de la pater familias la un alt fiu de familie care, dobândind bunurile familiale va avea resursele necesare pentru a oficia ceremoniile religioase dedicate străbunilor. ${ }^{16}$ Această stare de fapt i-a condus

\footnotetext{
${ }^{10}$ Fustel De Coulanges, op.cit., p. 77.

${ }^{11}$ Idem, p. 93.

${ }^{12}$ Ibidem.

${ }^{13}$ C. M. BRUNE, op.cit., p. 432.

${ }^{14}$ Este vorba, și în acest context, despre soția căsătorită cum manu.

${ }^{15}$ Fustel De Coulanges, op.cit., p. 93-94.

${ }^{16}$ C. M. BRUNE, op.cit., p. 444.
} 
pe unii autori la concluzia, inexactă din perspectiva noastră, că succesiunea testamentară a precedat-o pe cea legală. ${ }^{17}$

Prin urmare, în epoca vechiului drept roman, persoana aptă de a fi numită succesor a lui pater familias era absolut necesar să poată, în mod cumulativ, să dețină proprietatea defunctului, ${ }^{18}$ să perpetueze familia, respectiv să continue religia părintească. ${ }^{19}$

Față de cele arătate, ne întrebăm în ce măsură putem afirma că soția (căsătorită cum manu) dobândește în calitate de moștenitor civil legal o cotăparte în plină proprietate? Neputând oficia cultul casnic, soția nu poate dobândi proprietatea, fiind practic străină de esența noțiunii de succesor, astfel cum era aceasta concepută în epoca primitivă. Şi totuşi, Legea celor XII table îi atribuie o parte virilă în proprietate. Cum putem concilia aceste dispoziții?

\footnotetext{
${ }^{17}$ Pentru detalii, a se vedea ibidem.

18 Ceea ce juriștii contemporani înțeleg prin noțiunea de „drept de proprietate” diferă fundamental de concepția de la începuturile Romei. În perioada vechiului drept roman, proprietatea se confunda cu însuşi lucrul care formează obiectul dreptului de proprietate. Stăpânirea de care pomenește legea decemvirală și care este exercitată de șeful de familie asupra bunurilor era cunoscută sub denumirea de „dominium”. Până la Iustinian, proprietatea („proprietas”) nu a fost definită teoretic și nici nu a fost conceptualizată tehnico-juridic. Mircea Dan Вов, Manual elementar de drept privat roman, ed. Universul Juridic, București, 2016, p. 123-129. Menționăm că prin trimiterile pe care le facem, în cuprinsul acestei secțiuni, la noțiunea juridică de „drept de proprietate” înțelegem, de fapt, puterea lui pater familias de a dispune de bunurile familiei. Am optat pentru utilizarea termenului de „proprietate” din mai multe considerente. În primul rând, raportat la realitatea faptică a dreptului roman, prerogativele șefului de familie erau similare cu cele ale unui proprietar exclusiv. În al doilea rând, am folosit un termen contemporan cu scopul de a facilita accesul la informație al cititorului și de a-i ușura procesul de înțelegere al conținutului articolului.
}

${ }^{19}$ Idem, p. 433. 
În perioada pe care o analizăm, singura formă de căsătorie practicată de romani era căsătoria cum manu. ${ }^{20}$ Prin încheierea acestei căsătorii are loc ruperea legăturilor de agnațiune între femeie și familia de proveniență, având efectul unui capitis deminutio minima, ${ }^{21}$ fapt ce conduce la pierderea drepturilor de moștenire în familia sa. Însă, prin încheierea căsătoriei cum manu, soția intră în familia soțului ei în calitate de fiică, ${ }^{22}$ dobândind drepturi succesorale în baza legăturilor agnatice astfel stabilite. ${ }^{23}$

Drepturile succesorale ale soților nu sunt reciproce, iar existența și întinderea acestora variază în funcție de soțul care decedează cel dintâi, motiv pentru care vom analiza separat deschiderea moștenirii femeii și a bărbatului.

La decesul soției, soțul supraviețuitor nu va avea niciun drept succesoral deoarece femeia in manu mariti nu are capacitatea de a deține un patrimoniu personal. ${ }^{24} \mathrm{Cu}$ toate acestea, bărbatul va beneficia, în plină

\footnotetext{
${ }^{20}$ Analizând familia romană din perspectivă civilă, vom stabili că drepturile succesorale ale soțului supraviețuitor depind în totalitate de legitimitatea căsătoriei și a descendenților cu care soțul căsătorit cum manu concurează. Cu toate acestea, în timpul lui Iustinian s-au acordat concubinei și copiilor ei drepturi succesorale în proprietate, cu condiția ca la succesiunea defunctului să nu fie chemată soția sau descendenții legitimi. Thomas RüFNER, «Intestate Sucession in Roman Law», în KenNeth G. C. ReID, Marius J. DE WAAL and Reinhard Zimmermann, Comparative Succession Law, vol. II, ed. Oxford University Press, Oxford, 2015, p. 29.

${ }^{21}$ Gaius I.162-163.

${ }^{22}$ Gaius I. 111. Din punct de vedere juridic, soția este poziţionată loco filiae față de soț, respectiv de loco sororis față de copiii rezultaţi din căsătoria cum manu. George DuMITRIU, Dreptul de moștenire al soțului supraviețuitor la romani, ed. Tipografia ”Estetica”, București, 1931, p. 10. Pe de altă parte, din punct de vedere social și moral, femeia era foarte respectată și beneficia de autoritate. Jacques Ellul, Histoire des institutions. L'Antiquité, ed. Quadrige, Paris, 1999, p. 349.

${ }^{23}$ George DumitrIU, op.cit., p. 10; GR. C. CONDURATU, Compararea drepturilor succesorale ale soțului supraviețuitor în dreptul roman, codicile Callimachi și Caragea, Codul Napoleon și Codul Alexandru Ion I., ed. Tipografia Lucrătorilor Asociați, București, 1898, p. 13.

${ }^{24}$ George DumitriU, op.cit., p. 13.
} 
proprietate, de bunurile care au format obiectul dotei, ${ }^{25}$ el fiind proprietarul acestora de la momentul încheierii căsătoriei. ${ }^{26}$

În situația în care soția supraviețuiește bărbatului, aceasta are vocație succesorală concretă la moștenirea legală lui decuius în baza dispozițiilor Legii celor XII table ${ }^{27}$. Soția supraviețuitoare va dobândi, în calitate de heres sua et necessaria, ${ }^{28} \mathrm{o}$ cotă de moștenire în proprietate ${ }^{29}$ egală (per capita) cu

${ }^{25}$ Pentru detalii cu privire la situațiile care constituie excepția de la regulă păstrării bunurilor dotale, a se vedea Jean Philippe LevY, Andre CASTALDo, Histoire Du Droit Civil, 2e édition, ed. Dalloz, Paris, 2010, p. 1452.

${ }^{26}$ Soțul obține un avantaj patrimonial considerabil, deoarece dota constituită înainte de căsătorie se ridica, cel mai probabil, la venitul anual al familiei femeii. Thomas RüFNER, op.cit., p. 12.

${ }^{27}$ Este vorba despre Lex duodecim tabularum. Această lege a fost rezultatul muncii unei comisii formată din 10 persoane (decemvirii legibus scribundis) care a avut misiunea de a codifica vechiul drept cutumiar roman. Demersul a fost inițiat de presiunile exercitate de plebei care au solicitat acordarea posibilității tuturor de a cunoaşte normele juridice şi de a se asigura de corecta aplicare a acestora justițiabililor, independent de clasa politică din care făceau parte. Astfel, în anul 449 a. Chr., codificarea obiceiurilor juridice a fost publicată pe XII table de bronz. Considerată a fi „prima codificare adevărată”, Legea celor XII table cuprinde dispoziții de drept public şi privat, de drept substanțial, cât şi de drept procesual. Mircea Dan BoB, op.cit., p. 4243; Emil MolcuȚ, Drept privat roman. Terminologie juridică romană, ed. Universul Juridic, București, 2011, p. 39-40.

${ }^{28}$ Cuvântul „heres” provine din latinescul „herus” care semnifică „stăpân”. Rezultă astfel că, în concepția romană primitivă, prima clasă de moștenitori dobândea succesiunea în virtutea stăpânirii pe care o exercitau asupra bunurilor familiale încă din timpul vieții lui pater familias şi nu prin efectul unei transmisiuni universale, precum s-a stabilit ulterior. Aceasta este rațiunea pentru care acești moştenitori nu puteau refuza moștenirea, întrucât le revenea de drept. Dan OANCEA, op.cit., p. 163-165.

${ }^{29}$ Natura juridică a dreptului pe care soția supraviețuitoare îl dobândește ca moștenitor legal nu reprezintă, de regulă, un pericol pentru familia defunctului, întrucât la moartea soției, acele bunuri vor reveni fie descendenților, fie agnaților familiei soțului predecedat. Prin urmare, bunurile din masa succesorală a soțului vor ajunge, prin retransmitere, rudelor agnatice ale defunctului ca efect al deschiderii succesiunii femeii. Totodată, încheierea căsătoriei nu putea fi perfectată fără acordul tutorelui femeii, persoană aleasă dintre agnații defunctului său soț. Jean Philippe LevY, Andre CASTALDO, op.cit., p. 1534. 
cea a descendenților de același grad cu care venea împreună la moștenire. $3^{0}$ În lipsă de copii legitimi, soția îi înlătura de la succesiune pe agnații și pe cognații defunctului, dobândind întreaga masă succesorală în proprietate. ${ }^{31}$ Rațiunea acordării unor drepturi succesorale extinse soției supraviețuitoare rezidă în dorința de a compensa pentru avantajul patrimonial pe care aceasta i l-a adus soțului, în momentul încheierii căsătoriei, prin absorbția bunurilor femeii în patrimoniul defunctului. ${ }^{2}$

Puterea exercitată de pater familias asupra descendenților şi a soției are caracter viager. Așadar, la momentul decesului, omnipotența lui pater familias asupra persoanelor alieni iuris încetează, iar drept consecință soția devenea o persoană sui iuris. 33

Independența soției, după moartea șefului de familie, este relativă. Dacă este adevărat că aceasta nu se mai găsește sub puterea unui pater

30 Exista posibilitatea ca la succesiunea şefului de familie să vină, alături de soția supraviețuitoare și de alți fii, un nepot de fiu predecedat. Acesta din urma va veni la moștenire prin reprezentarea ascendentului său, moștenirea în acest caz împărțindu-se pe tulpini (per stirpes). Gaius III.8.

${ }^{31}$ GR. C. CONDURATU, op.cit., p. 13.

${ }^{32}$ GR. C. CONDURATU, op.cit., p. 13. Situația aceasta se explică prin faptul că la momentul contractării unei căsătorii cum manu, întreaga avere a soției sui iuris trecea în patrimoniul lui pater familias (soțul său sau tatăl acestuia). În cazul în care soția era alieni iuris, deci sub puterea unei șef de familie, cutuma spunea ca acesta să îi dăruiască anumite bunuri mobile și imobile pentru a susține sarcinile căsătoriei ( ad onera matrimonii sustinenda), sub forma unei dote (dos). Dota intra în proprietatea noului șef de familie care, la început, exercita prerogative nelimitate în ceea ce privește aceste bunuri, sub rezerva folosirii lor în vederea satisfacerii necesităților menajului comun. Vladimir HANGA, Drept privat roman, ed. Didactică și Pedagogică, București, 1977, p. 198-199. De asemenea, în situația desfacerii căsătoriei, bunurile dotale nu erau restituite, ca atare, soției. În schimb, inechitatea este înlăturată de faptul că aceasta dobândea drepturi succesorale în proprietate egale cu orice descendent aflat sub puterea lui pater familias la momentul decesului său. Julie DoDDs, The impact of The Roman Law of Succession and Marriage on Women's Property and Independence, Melbourne University Law Review nr. 18/1992, p. 909.

${ }^{33}$ Dan OANCEA, op.cit., p. 83. 
familias, în lipsa unei dispoziții testamentare, ea este pusă sub tutela legitimă celui mai apropiat agnat sui iuris, pe întreaga durată a vieții sale. ${ }^{34}$ Astfel, soția supraviețuitoare era privată de atributul de dispoziție asupra bunurilor pe care le dobândea în proprietate din succesiunea soțului său, tutorele fiind cele care avea autoritate asupra patrimoniului său. 35 Scopul pentru care s-a instituit această măsură era justificat de existența unei pretinse neputințe naturale, ${ }^{36}$ a unei slăbiciuni datorată apartenenței la sexul feminin. ${ }^{37}$ În realitate, instituția tutelei nu era adresată protejării drepturilor femeii, ci a intereselor proprii ale grupării agnatice, care urmărea prezervarea patrimoniului familial..$^{8}$ În perioada vechiului drept roman, instituția tutor mulieris avea competența materială de a încuviința (auctoritas) vânzarea bunurilor importante (res mancipi), transmiterea patrimoniului sau a unei fracțiuni din acesta prin testament, contractarea unei obligații etc. $39 \mathrm{Cu}$ privire la bunurile aparținând femeii devenite sui iuris ca urmare a decesului lui pater familias sub a cărui putere se afla, este important de menționat faptul

\footnotetext{
${ }^{34}$ Fustel De Coulanges, op.cit., p. 79; Mircea Dan Bob, op.cit., p. 122.

${ }^{35}$ Autoritatea tutorelui nu se extinde asupra persoanei însăşi, ci se limitează la bunurile femeii. Paul GIDE, Étude sur la condition privée de la femme dans le droit ancien et moderne et en particulier sur le Sénatus-consulte Velléien, ed. Durand et Pédone-Lauriel, Paris, 1867, p. 117. ${ }^{36}$ Neputința naturală se traducea, în esență, în lipsa de putere fizică a femeii care era necesară, în epoca primitivă, în lupta pentru existență. Ulterior, constatându-se că acest motiv era insuficient, instituirea tutelei s-a justificat pe motiv de inferioritate intelectuală a femeii (este bine-cunoscut faptul că femeile erau considerate un caz de excepție în aplicarea prezumției nemo censetur ignorare legem). Pentru mai multe detalii, a se vedea C. HAMANGIU, Matei G. NICOLAU, Dreptul roman, ed. Librăriei SOCEC \& Co., București, 1930, p. 349-350.

37 Dorin JOREA, Donații din bunurile părintelui nebun - O privire istorică, Studia Iurisprudentia nr. 4/2017, p. 99.

${ }^{38}$ La moartea femeii, aceștia sunt moştenitorii prezumtivi ai săi, în detrimentul descendenților ori a altor rudelor de sânge ale soției. Paul GIDE, op.cit., p. 230.

${ }^{39}$ Vladimir Hanga, op.cit., 1977, p. 230; C. HamangiU, Matei G. NiCOlaU, op.cit., p.353.
} 
că tutorele nu avea gestiunea patrimoniului femeii, ${ }^{40}$ fiind doar însărcinat săşi dea încuviințarea la încheierea actelor de dispoziție.

Așadar, observăm că exercitarea, în calitate de proprietar, a tuturor atributelor dreptului absolut de proprietate dobândit de soția din devoluțiunea legală este incompatibilă cu lipsa de capacitate de exercițiu a acesteia în privința încheierii actelor juridice translative de proprietate, ${ }^{41}$ precum și cu imposibilitatea oficierii cultului casnic. Iată-ne ajunși într-un impas.

Soluția pe care o propunem este de a trata aparentul drept de proprietate al soției supraviețuitoare asemenea unui drept real în uzufruct. $4^{2}$ Pe de-o parte, în lipsa exercitării autonome a atributului de dispoziție, 43 soția beneficiază, în realitate, numai de usus și fructus, fapt ce ne conduce, mai

\footnotetext{
${ }^{40}$ Vladimir Hanga, op.cit., p. 231; C. HamangiU, Matei G. NicOlaU, op.cit., p.352-353.

${ }^{41}$ Pentru a se obliga juridic în vederea transmiterii patrimoniului, femeia avea nevoie de consimțământul tutorelui.

42 În doctrină s-a afirmat că soția se comportă „aproape ca un simplu uzufructuar”. Fustel DE COUlANGES, op.cit., p. 79. Desigur, calificarea moștenitorului ca uzufructuar este realizată folosind terminologia juridică actuală. În perioada vechiului drept roman, uzufructul era considerat o servitute personală care permitea detașarea diferitelor prerogative rezultate din stăpânirea unui bun, în beneficiul unei alte persoane, diferită de proprietar. Mircea Dan BoB, op.cit., p. 157. Mai mult decât atât, în dreptul roman recunoașterea unui drept subiectiv în uzufruct este condiționată de asigurarea unei acțiuni, înțeleasă ca mijloc procedural de apărare a unui interes legitim. Mircea Dan Bов, op.cit., p. 81. Or, în epoca pe care am analizat-o în această secțiune, soției supraviețuitoare nu îi era atribuită o acțiune confesorie de uzufruct (în terminologia actuală) în caz de tulburare a folosinței de către un terț. Însă, strict raportat la modalitatea în care soția supraviețuitoare putea să administreze bunurile provenite din succesiune și la imposibilitatea acesteia de a oficia cultul casnic, considerăm că, din perspectivă dreptului material, folosința exercitată se aseamănă cu cea a unui uzufructuar.

${ }^{43}$ În cea mai veche perioadă a dreptului roman, din perspectivă strict tehnică, nu se poate vorbi despre existența unui atribut de dispoziție. Cu toate acestea, am optat pentru această formulare cu scopul de a ușura înțelegerea studiului, dar și pentru a apropia noțiunile juridice din acea epocă de secolul al XXI-lea. Mai mult, abordarea ne ajută la înțelegerea surselor de inspirație ale legislațiilor romano-germanice care au succedat.
} 
mult, către concluzia existenței unei servituți personale. În acest caz, nudaproprietate este deținută de categoria agnaților, al cărei reprezentant este tutorele femeii. Pe de altă parte, în lipsa unor descendenți de sex masculin care să perpetueze cultul casnic, soția sui iuris nu poate dispune de bunurile dobândite din succesiunea defunctului pentru a aduce ofrandă zeilor protectori ai familiei și nici nu este acceptată în poziția de conducătoare a cultului religios. Prin urmare, aceasta, deși egală din perspectivă succesorală cu descendenții de sex masculin, restricțiile impuse de ordinea legală, în materie de tutelă și religios, în privința cultului casnic, declanșează o „alchimie” juridică a naturii dreptului de proprietate cu rezultatul transformării lui într-un drept de uzufruct. 44

\section{Dreptul pretorian}

Desfacerea căsătoriei prin decesul soțului oferea posibilitatea soției supraviețuitoare de a încheia o nouă conventio in manum. Aceasta presupunea însă obținerea, în mod obligatoriu, a încuviințării tutorelui (rudă civilă cu defunctul său soț). Or, cum tutorele nu era interesat ca femeia, printro nouă căsătorie, să rupă legăturile agnatice cu familia defunctului, fapt ce conducea implicit la pierderea drepturilor sale succesorale şi la trecerea patrimoniului familial în stăpânirea unor alogeni, acesta se dovedea a fi rareori de acord cu oficierea căsătoriei.45 Dezideratul de a forma o nouă familie era urmărit atât de stat, la nivel macro, în vederea creșterii

\footnotetext{
${ }^{44}$ Atribuirea drepturilor succesorale în uzufruct soției supraviețuitoare conferă suport istoric, încă din perioada vechiului drept roman, pentru soluțiile legislative consacrate de Codul civil italian de la 1865, modificare legislativă a art. 767 Cod civil francez din 1891 etc.

${ }^{45}$ Paul GIDE, op.cit., p. 126-127.
} 
natalității, ${ }^{46}$ cât și de soția supraviețuitoare care, la nivel micro, căuta un sprijin material și afectiv.

Pentru a concilia aceste interese contrare, s-a propus 47 despărțirea noțiunilor, până în acel moment indisolubile, de căsătorie şi de putere părintească (manus).48 Prin urmare, consacrarea unei noi tipologii de căsătorie, sine manu, 49 care nu rupea legăturile agnatice cu familia de origine a femeii, lăsând intacte drepturile succesorale ale agnaților și nu necesita, pentru încheierea sa valabilă, consimțământul tutorelui, reprezenta, la momentul respectiv, soluția ideală. $5^{\circ}$

Consecințele juridice declanșate de încheierea unei căsătorii sine manu prezintă diferențe esențiale față de realizarea unei conventio in manum. Astfel, femeia căsătorită sine manu rămânea în puterea părintească (patria potestas) a tatălui său care păstra, în continuare, alături de drepturile succesorale și dreptul de a dispune de aceasta (prin pedepsire la moarte, prin vânzare etc.). ${ }^{51}$ Căsătoria sine manu nu conferă soțului manus asupra

\footnotetext{
${ }^{46}$ S-a afirmat că însuși scopul căsătoriei era creșterea populației cetății. J. L. BARTON, Marriage in Roman Law, Law \& Justice: The Christian Law Review nr. 52/1977, p. 9.

${ }^{47}$ Paul GIDE, op.cit., p. 127.

${ }^{48}$ Ibidem.

${ }^{49}$ Pentru încheierea valabilă a căsătoriei libere (sine manu) trebuiau întrunite două elemente esențiale: intenția ambilor soți de a se angaja într-o căsătorie (affectio maritalis) și conviețuirea materială (honor matrimonii). Existența căsătoriei nu era condiționată de îndeplinirea unor formalități religioase sau civile. Vladimir HANGA, op.cit., p. 195-196. Astfel, privită din exterior, căsătoria sine manu nu se distinge cu nimic de concubinaj. Jacques ElLUL, op.cit., p. 410. S-a susținut că această poziție socială a soției se datorează frecventelor divorțuri din epoca clasică. Jean Philippe LEVY, Andre CASTALDO, op.cit., p. 1535.

${ }^{50}$ Căsătoria sine manu a devenit uzuală începând cu anul 250 a. Chr. Jacques ElLul, op.cit., p. 353.

${ }^{51}$ Paul GIDE, op.cit., p. 128.
} 
femeii, $5^{2}$ dar drepturile sale rezultate din calitatea de soț îi permit să-şi exercite puterea maritală în situația în care femeia comite anumite delicte, putând totodată să dispună, fără niciun control, asupra dotei primite.53 Așadar, puterea părintească și cea tutelară, pe de-o parte și puterea maritală pe de alta nu se exclud, ci dimpotrivă, concurează. 54

S-a pus următoarea întrebare: cum vor fi soluționate conflictele inevitabile intervenite între pater familias și soțul femeii?55 Care instituție va beneficia de o protecție juridică mai consolidată: familia sau patria potestas?

În literatură s-a arătat că destrămarea unei familii prin folosirea prerogativelor conferite de patria potestas este contrară ordinii publice, $\mathrm{cu}$ excepția unor motive bine întemeiate. $5^{6}$ Așadar, drepturile lui pater familias asupra fiicei sale căsătorită sine manu sunt limitate prin protecția sporită acordată instituției căsătoriei.

Totodată, Antoninus Pius a interzis ca o căsătorie armonioasă să fie întreruptă de către tatăl soției, atâta timp cât problema în discuție nu este stabilirea locului în care femeia este mai protejată.57 Așadar, s-a acordat

\footnotetext{
${ }^{52}$ S-a afirmat că, la încheierea căsătoriei sine manu, femeia intră în casa bărbatului, dar nu și în familia sa. Edouard LABOULAYE, Recherches sur la condition civile et politique des femmes, depuis les romains jusqu'à nos jours, ed. Imprimerie de Fain et Thnot, Paris, 1843, p. 33.

${ }^{53}$ Paul Gide, op.cit., p. 129.

${ }^{54}$ Ibidem.

55 Pentru soluționarea unor astfel de conflicte s-a înființat tribunalul familial (le tribunal domestique). Pentru detalii cu privire la componența acestei instanțe, la competența materială și la procedura de judecată, a se vedea Paul Gide, op.cit., p. 130.

56 Johannes PlATSCHEK, „ «My Lord, save me from my father!» Paternal power and Roman Imperial State”, în Nova Ratione. Change of paradigms in Roman Law, ed. Harrassowitz Verlag, Wiesbaden, 2014, p. 53.

${ }^{57}$ Bene concordans matrimonium separari a patre divus Pius prohibuit, itemque a patrono libertum, a parentibus filium filiamque: nisi forte quaeratur, ubi utilius morari debeat. PS 5.6.15. în Johannes PlatscheK, op.cit. p. 54. Pentru traducere, a se vedea Santiago Castán
} 
prioritate protecției juridice a căsătoriei în detrimentul puterii părintești (patria potestas)..$^{8}$

Din exemple enunţate, observăm că tensiunea naturală existentă între puterea părintească și puterea maritală asupra femeii s-a soluționat prin acordarea întâietății instituției căsătoriei în defavoarea puterii părintești care, deși subzistă în persoana tatălui soției (pater familias), acesta nu o poate exercita nelimitat. 59

După războaiele punice, căsătoria cum manu cade treptat în desuetudine, ${ }^{60}$ iar utilizarea căsătoriei sine manu este tot mai frecventă.

Consecințele încheierii unei căsătorii sine manu se resimt și în plan succesoral. Spre deosebire de soția aflată sub puterea soțului ei, femeia căsătorită sine manu nu avea vocație la moștenirea soțului, deoarece neintrând în familia sa, nu devenea rudă civilă cu acesta, ea rămânând sub patria potestas a tatălui ei, în familia de origine. ${ }^{61}$ În acest caz, dacă femeia este alieni iuris, tot ce va dobândi în timpul căsătoriei, aparține tatălui ei, iar în situația în care este independentă, ea este pusă sub tutela agnaților. ${ }^{62}$

Potrivit regulilor devoluţiunii legale cuprinse în Legea celor XII table, soția căsătorită sine manu nu aparținea primei clase de moștenitori, întrucât aceasta nu se afla sub puterea șefului de familie, prin ipoteză a defunctul său

PÉRez-Gómez, El Matrimonio Como Estrategia En La Carrera Política Durante El Último Tramo de la República, în Revista Internacional de Derecho Romano, octombrie 2011, p. 377. ${ }^{58}$ Johannes PlatscheK, op.cit., p. 54; Paul GIDE, op.cit., p. 150.

${ }^{59}$ Paul Gide, op.cit., p. 149.

${ }^{60}$ Mircea Dan BoB, op.cit., p. 107.

${ }^{61}$ Edouard LaboulaYe, op.cit., p. 23; George Dumitriu, op.cit., p. 18-19.

${ }^{62}$ George DumitriU, op.cit., p. 13; Vladimir HANGA, op.cit., p. 316-317. 
soț.63 Totodată, femeia nu putea fi inclusă în clasele subsecvente, neaflânduse într-o legătură de agnațiune cu pater familias. ${ }^{64}$

Dezbaterea moștenirii comportă soluții juridice diferite, în funcție de soțul căruia i se deschide primul succesiunea.

La moștenirea soției căsătorite sine manu, soțul supraviețuitor nu are vocație succesorală, fiind în afara grupului rudelor sale civile. ${ }^{65}$ Acest aspect nu este o noutate în materie succesorală, întrucât și sub imperiul dispozițiilor vechiului drept roman, soțul căsătorit cum manu nu este chemat la moștenirea soției. Cu toate acestea, la prima vedere, poate părea paradoxal ca soțul supraviețuitor, dacă se căsătorise sine manu să aibă totuși o poziție economică mai dezavantajoasă, decât dacă încheie o convenio in manum. Explicație rezidă în păstrarea legăturilor de putere între soție și familia de origine, întrucât totalitatea achizițiilor acesteia, pe durata mariajului, revin fie părintelui său, fie chiar soției în ipoteza în care aceasta era independentă (sui iuris), deci era titulara unui patrimoniu propriu. $66 \mathrm{O}$ altă justificare a dezechilibrului menționat se regăsește în regimul matrimonial al căsătoriei sine manu (separația de bunuri), spre deosebire de căsătoria cum manu, unde bunurile soției sunt absorbite automat în patrimoniul soțului său. ${ }^{67}$ Așadar,

\footnotetext{
${ }^{63}$ Este interesant de analizat apelativul folosit pentru femeia căsătorită: în vechiul drept roman se utiliza termenul de mater familias, iar după generalizarea căsătoriei sine manu, noțiunea de matrona sau uxor. Denumirea de mater familias, prin includerea termenului familias, demonstrează faptul că femeia avea drepturi generate de instituția familiei (precum pater familias, filia familias etc.). Pe de altă parte, noțiunile de matrona sau uxor conduc la concluzia inexistenței drepturilor succesorale în familia în care a intrat prin încheierea căsătoriei. George DUMitriu, op.cit., p. 18; Edouard LABOUlAYE, op.cit., p. 33.

${ }^{64}$ Desigur, soția căsătorită sine manu păstrează toate drepturile succesorale pe care le deține în familia de origine, în calitate de fiică aflată sub patria potestas a tatălui său.

${ }^{65}$ Rudenia de sânge fiind evident exclusă între soți.

${ }^{66}$ C. Hamangiu, Matei G. Nicolau, op.cit., p. 301; George Dumitriu, op.cit., p. 19.

${ }^{67}$ Jacques ELLUL, op.cit., p. 354.
} 
încă din timpul vieții soției, partenerul său este dezavantajat din perspectivă financiară, urmând ca la decesul femeii să fie exclus din categoria moştenitorilor datorită lipsei vocației generale la moştenire.

În cazul predecesului soțului, regulile din perioada Regalităţii exclud soția supraviețuitoare de la moștenirea defunctului său soț. Întrucât, la data decesului acestuia din urmă, soția nu se află sub puterea sa (manus), ea este înlăturată de la devoluțiunea legală reglementată de Legea celor XII table. Neîndeplinirea condiției vocației succesorale plasează femeia pe o poziție de vădită inechitate. ${ }^{68}$ Pe durata căsniciei, soția contribuie la creșterea patrimoniului soțului său preponderent prin ajutorul dat în gospodărie, dar la decesul acestuia nu beneficiază de bunurile respective, deoarece revin, potrivit legii decemvirale, erezilor soțului decedat. 69

Reglementarea în materia zestrei vine să corijeze unele dintre aceste deficiențe. Astfel, soția căsătorită sine manu are aptitudinea de a dobândi bunurile dotale intrate în patrimoniul defunctului prin încheierea căsătoriei,70 dobândind o oarecare independență financiară. ${ }^{11}$

\footnotetext{
${ }^{68}$ Gaius III.25.

${ }^{69}$ Care nu sunt, în mod obligatoriu, exclusiv descendenții comuni ai soților.

${ }^{70}$ La desfacerea căsătoriei, soția supraviețuitoare putea intra în posesia dotei în următoarele situații: fie bărbatul lăsa un legat prin care dispunea restituirea dotei (relegatum dotis), fie părțile stipulau o clauză de restituire a bunurilor dotale în caz de încetarea a căsătoriei prin însuși contractul de căsătorie (stipulatio). În situația în care soții nu și-au luat măsurile de precauție la momentul constituirii dotei sau soțul nu a înțeles să o gratifice pe soția sa cu dota dobândită în plină proprietate la căsătorie, atunci s-a recunoscut o obligație cutumiară (sancționată printr-o acțiune rei uxoriae). În cadrul acestei acțiuni, judecătorul aprecia în funcție de circumstanțele cauzei dacă se impune sau nu restituirea bunurilor dotale. Ulterior, orientarea jurisprudenței a fost în sensul obligării moștenitorilor la înapoierea dotei în cazul decesului soțului. Jean Philippe Levy, Andre CASTALDO, op.cit., p. 1451-1452. Pentru opinii doctrinare similare, dar care nu abordează o analiză aprofundată, a se vedea Paul GIDE, op.cit., p. 150; Thomas RÜFNER, op.cit., p. 12; George DUMITRIU, op.cit., p. 13.
}

${ }^{71}$ Paul GIDE, op.cit., p. 150. 
Considerăm că posibilitatea acordării bunurilor dotale nu constituie un argument suficient pentru a justifica excluderea soției de la moștenirea soțului său. Atâta timp cât dreptul civil nu îi conferă vocație succesorală soției, orice contribuție proprie a femeii la patrimoniul familiei este implicit desconsiderată, rolul ei reducându-se la un simplu sprijin afectiv şi la naşterea descendenților.

Transformările petrecute în realitatea socială a vremii, în construcția familiei și în schimbarea viziunii asupra căsătoriei, au condus la crearea unor inechități în materie succesorală, în special în cazul soției căsătorită sine manu. Dispozițiile legii decemvirale nu mai corespundeau cu nevoile sociale, astfel încât intervenția pretorului a apărut ca o necesitate.

Între sec. I a. Chr. și sec. I p. Chr., pretorul a stabilit noi reguli în materia devoluțiunii legale a moștenirii, cunoscute sub numele de succesiunea pretoriană (bonorum possessio)..$^{22}$ Prin aceste măsuri, pretorul a urmărit să ocrotească persoanele care nu aveau vocație la moştenire în temeiul legii decemvirale, respectiv rudele de sânge și soții căsătoriți sine manu.73 În ceea ce privește aceste din urmă personaje, pretorul le-a acordat bonorum possessio, introducându-i în cea de-a patra categorie de moștenitori pretorieni (bonorum possessio unde vir et uxor).

Potrivit regulilor moștenirii pretoriene, soția sau soțul supraviețuitor erau chemați al moștenire numai în cazul în care nu existau succesibili din

\footnotetext{
${ }^{72}$ Vladimir HANGA, op.cit., p. 316. Mircea Dan BOB, op.cit., p. 322; Dan OANCEA, op.cit., p. 166168.

${ }^{73}$ Dan OANCEA, op.cit., p. 166.
} 
categoriile anterioare, respectivi rude agnatice sau cognatice. ${ }^{74}$ Totodată, pretorul este primul care conferă soților vocație succesorală reciprocă. 75

La prima vedere, inovația pretoriană în materie succesorală rezolvă problema vocației generale la moștenire între soți.76 Însă, în realitate, care erau expectanțele concrete ale soțului supraviețuitor ca moștenitor $a b$ intestato?

În succesiunea pretoriană, soțul supraviețuitor primea numai posesiunea bunurilor succesorale (bonorum possessio),77 acesta fiind doar

\footnotetext{
${ }^{74}$ Este vorba despre categoriile bonorum possessio unde liberi, bonorum possessio unde legitimi, bonorum possessio unde cognati. Dan OANCEA, op.cit., p. 167-168; Mircea Dan BoB, op.cit., p. 322; Thomas RÜFNER, op.cit., p. 14-17.

75 Dan OANCEA, op.cit., p. 168.

${ }^{76}$ S-a susținut că inovația pretoriană poate apărea ca o bulversare a sistemului succesoral de drept civil instituit de dispozițiile Legii celor XII table. Jean Philippe LEVY, Andre CASTALDO, op.cit., p. 1143.

77 În literatura de specialitate s-a susținut că existau situații în care o persoană chemată la moştenire după dreptul civil venea în conflict cu un moștenitor pretorian. Vladimir HANGA, op.cit., p. 317. Practic, conflictul nu putea produce între un soț supraviețuitor care culege moștenirea conform jus civile și unul care vine în calitate de moștenitor pretorian. Jean Philippe LEVY, Andre CASTALDO, op.cit., p. 1143. În primul rând, premisa acestui potențial conflict între moștenitori o constituie încheierea a două tipuri de căsătorii: cum manu și sine manu. Astfel, un bărbat ajunge să fie soțul a două femei. Or, în dreptul roman, era consacrat de dreptul pozitiv principiul monogamiei. Cod. 5, 5, 2. (,Neminem, qui sub dicione sit Romani nominis, binas uxores habere posse vulgo patet, cum et in edicto praetoris huiusmodi viri infamia notati sint."). Pentru detalii a se vedea Andrew T. BIKRKAN, Marriage in Roman Law, Yale Law Journal, nr. 5/1907, vol. XVI, p. 303. În al doilea rând, dacă la moștenire soțului decedat vine o soție supraviețuitoare căsătorită cum manu, aceasta se va poziționa în prima clasă de moștenitori (sui heredes), înlăturând celelalte clase subsecvente, deci inclusiv pe cea de-a doua soție aflată în clasa a patra (bonorum possessio unde vir et uxor). Așadar, și sub acest aspect este exclusă posibilitatea intervenirii unui conflict între cele două categorii de moştenitori legali.
} 
asimilat unui moștenitor civil (loco heredis). ${ }^{8}$ De asemenea, vocația concretă la moștenire îi conferea soțului mai multe mijloace procesuale de apărare.79

Observăm că soțul supraviețuitor este inclus în clasa a patra de moștenitori, acordându-i-se bonorum possessio unde vir et uxor, ${ }^{80}$ fiind chemat la moștenire în rang ultim și excepțional, în lipsă de cognați până la gradul al 6-lea sau al 7-lea. ${ }^{81}$ Efectiv, șansele ca soțul supraviețuitor să vină la moştenire sunt extrem de reduse, ${ }^{82}$ întrucât existau prea puține situații în care succesiunea să nu fie acceptată de un cognat până la gradul al 6-lea sau al 7lea.

Or, în aceste circumstanțe, considerăm că prin intervenția pretorului 83 în domeniul dreptului succesoral procesual și material s-a încercat alinierea dispozițiilor desuete ale normelor jus Quiritium cu nevoile societății romane de la finele Republicii. Reforma nu a înlăturat toate neajunsurile semnalate, ${ }^{84}$

\footnotetext{
${ }^{78}$ Vladimir HANGA, op.cit., p. 317. Moștenitorii pretorieni, inclusiv soțul supraviețuitor, erau nevoiți să formuleze o petiție adresată pretorului. Pentru detalii cu privire la procedura succesorală pretoriană, a se vedea Jean Philippe LEVY, Andre CASTALDO, op.cit., p. 1363.

${ }^{79} \mathrm{O}$ primă posibilitate o reprezintă interdictele posesorii, considerate de unii autori ca fiind singurele mijloace procesuale de apărare. În acest sens, a se vedea Jean Philippe LEVy, Andre CASTALDO, op.cit., p. 1143. Alături de interdicte, moștenitorii pretorieni aveau la dispoziție acțiuni cu ficțiunea calităţii de moștenitor civil (fictio se herede). Vladimir HANGA, op.cit., p. 317; Gaius IV.34.

${ }^{80}$ Thomas RÜFNER, op.cit., p. 17.

${ }^{81}$ Jean-Philippe LEVY, Andre CASTALDO, op.cit., p. 1144-1145.

82 Thomas RÜFNER, op.cit., p. 28.

${ }^{83}$ În postura de viva vox iuris (de voce vie a dreptului).

${ }^{84}$ Pentru o expunere punctuală a poziției defavorabile a soțului supraviețuitor în cadrul moștenirii ab intestato, a se vedea Valerius M. CiUC̆̌, Drept roman. Lecțiuni, vol. II, ed. a II-a, ed. Universității „Alexandru Ioan Cuza” Iași, 2014, p. 749-750.
}

\section{6}


dar a constituit un pas important în vederea recunoaşterii drepturilor de moștenire efective ale soțului supraviețuitor în succesiunea $a b$ intestato. ${ }^{85}$

Am văzut că soția supraviețuitoare, căsătorită cum manu, cu toate că era sui heredes și beneficia de o cotă parte în plină proprietate, în fapt, situația ei juridică se asemăna mai mult cu cea a unui uzufructuar. ${ }^{86}$ Așadar, în cadrul succesiunii pretoriene putem susţine în continuare aceeași concluzie cu privire la soția căsătorită sine manu?

Pentru a putea oferi un răspuns, este necesar să analizăm schimbările care s-au produs la nivelul instituției tutelei femeii între secolul I a. Chr şi secolul al III-lea p. Chr.

Începând cu finele Republicii, au început să se producă transformări semnificative în privința instituției tutelei femeii cauzate preponderent de tendințele tot mai crescute de emancipare a femeii, accentuate de scăderea puterii lui pater familias asupra grupului familial și de declinul legăturilor agnatice. ${ }^{87} \mathrm{Cel}$ de-al doilea război punic a condus la scăderea dramatică a numărului de bărbați, fapt ce a determinat schimbarea statutului juridic al femeilor din alieni iuris în sui iuris. Cu toate că, în continuare, era numit un tutore pentru femeile sui iuris, acesta având propriile probleme cauzate de instabilitatea perioadei, supravegherea acestuia era mai mult formală. Așadar, plecând în război, bărbații au fost nevoiți să încredințeze

\footnotetext{
${ }^{85}$ Desigur, inechitatea instituită de dreptul civil și dreptul pretorian cu privire la drepturile de moștenire ale soțului supraviețuitor este surmontată, într-o oarecare măsură, de posibilitățile largi ale șefului de familie de a dispune de bunuri în favoarea soției. Însă, întrucât centrul de interes al tezei gravitează în jurul moștenirii legale, ne vom rezuma numai la anumite constatări în ceea ce privește drepturile moștenitorilor în devoluțiunea testamentară.

${ }^{86}$ A se vedea supra.

${ }^{87}$ Vladimir HANGA, op.cit., p. 231. Verena HALBWACHS, «Women as legal actors» în Paul J. DU Plessis, Ando Clifford \& Tuori KaIUs (dir.), The Oxford handbook of Roman law and society, Oxford, Oxford University Press, 2016, p. 449.
} 
administrarea patrimoniului soțiilor și fetelor, acestea din urmă devenind independente din punct de vedere economic și social. ${ }^{88}$ Observăm că, în această perioadă, soția supraviețuitoare, deși continuă să fie lipsită de capacitate de exercițiu și deci pusă sub tutelă, acesteia i se permite să-și aleagă tutorele. ${ }^{89}$ De asemenea, datorită reducerii formalismului în privința încheierii anumitor act juridice, auctoritas tutoris îşi pierde din importanță. $9^{90}$

Octavian Augustus, animat de necesitatea creșterii natalităţii poporului roman, prin lex Iulia Papia Poppea din anul 9 p. Chr. a decis ca femeile născute libere (ingenuae), care aveau trei copii, precum și femeile dezrobite cu patru copii să aibă capacitate deplină de exercițiu, nemaifiind nevoite să fie puse sub tutelă. ${ }^{11}$ Reformele au continuat, astfel că împăratul Claudius, prin lex Claudia de tutela mulierum, ${ }^{92}$ a desființat tutela legitimă a agnaților. 93

Așadar, este ilustrativă susținerea potrivit căreia, în dreptul clasic, „tutela femeilor este mai mult o amintire istorică decât o realitate juridică”. 94

Poziția socială a Terentiei, soția lui Cicero, este elocventă în acest context. Potrivit surselor vremii, aceasta își conducea propriile afaceri

\footnotetext{
${ }^{88}$ Eva Cantarella, «Women and patriarchy in roman law» în Paul J. Du Plessis, Ando Clifford \& Tuori KaIUs (dir.), The Oxford handbook of Roman law and society, Oxford, ed. Oxford University Press, 2016, p. 426.

${ }^{89}$ Situație în care tutela devenea pur formală, tutorele fiind, de fapt, o persoană de încrederea a femeii. Pentru detalii cu privire la modalitatea efectivă de alegerea a tutorelui, a se vedea Vladimir Hanga, op.cit., p. 231; C. HAMANGIU, Matei G. NiCOlaU, op.cit., p.349-352; Jacques ELLUL, op.cit., p. 410.

${ }^{90}$ Verena HalBWACHS, op.cit., p. 449.

${ }^{91}$ Gaius I.145.; Eva CANTARELLA, op.cit., p. 425.

${ }^{92}$ Data adoptării acestei legi este necunoscută. George MousouraKIs, Fundamentals of Roman Privat Law, ed. Springer, eBook, p. 357.

${ }^{93}$ Gaius I.171.; Vladimir HANGA, op.cit., p. 231.

${ }^{94}$ C. Hamangiu, Matei G. NicolaU, op.cit., p.348-349.
} 
singură, susținea financiar cariera politică a lui Cicero, și-a sprijinit copiii când soțul său nu a deținut resursele materiale necesare, și-a înstrăinat singură bunuri din patrimoniu etc. Toate aceste acte materiale de dispoziție le-a încheiat în nume propriu, fără a apărea vreo mențiune cu privire la tutorele său. $95 \mathrm{Cu}$ toate că, cel mai probabil, aceasta era încredințată unui tutore, este îndoielnică implicarea lui activă și efectivă în viața economică a femeii. 96

Prin urmare, în dreptul clasic, femeia independentă avea capacitate juridică de a încheia contracte în nume propriu, putând dispune de bunurile din patrimoniul său, fără ca voința să-i fie în mod real cenzurată de tutorele său. ${ }^{97}$

Considerăm că, începând cu dreptul clasic, nu se mai susține afirmația potrivit căreia drepturile soției supraviețuitoare sunt mai degrabă asemănătoare cu cele în uzufruct. Schimbările sociale privitoare, în special, la construcția familiei romane și la poziția femeii în sânul acesteia au determinat anumite intervenții juridice. Cele mai importante, sub aspectul problematicii pe care o analizăm, au survenit, cu precădere, în reglementarea căsătoriei, a puterii părintești și în ceea ce privește tutela mulierum. În final, în cazul puțin probabil în care soția supraviețuitoare este chemată la moștenirea pretoriană şi culege bunuri din masa succesorală a defunctului său soț, dobândește un

\footnotetext{
${ }^{95}$ S-a arătat că drepturile femeilor de a participa în circuitul economic, deși nu au fost atât de extinse ca cele ale bărbaților, în perioada dreptului clasic și a celui postclasic, acestea au fost consistente. Pentru detalii și exemple, a se vedea Wethmar-Lemmer, The Legal Position of Roman Women: A Dissenting Perspective, Fundamina nr. 12/2006, p. 178 și urm.; Jane F. GARDNER, Women in Roman Law \& Society, ed. Indiana University Press, Marea Britanie, 1991, p. 233-255.

${ }^{96}$ Pentru mai multe detalii, a se vedea Jully DodDs, op.cit. p. 910.

${ }^{97}$ În această perioadă, tutela mulierum a devenit o instituție pur formală. Wethmar-LEMMER, op.cit., p. 174 .
} 
veritabil drept de proprietate asupra acestora, pentru că îl exercita în plenitudinea sa, cu condiția obținerii unui consimțământ pur formal al tutorelui.

Prin urmare, în perioada clasică, putem afirma că dreptul de proprietate dobândit de soția supraviețuitoare prin moștenirea legală s-a întregit, în fapt, prin cumularea tuturor atributelor.

\section{Dreptul imperial. Legislația lui lustinian}

Reformele pretoriene în materie succesorală au introdus în clasele de moștenitori persoane a căror înlăturare de la devoluțiunea legală dictată de dispozițiile Legii celor XII table a fost considerată inechitabilă. $9^{8} \mathrm{Cu}$ toate că pretorul a oferit, pentru prima dată, calitatea de moştenitor rudelor de sânge (cognaților), acestea erau înlăturate de la moștenire de către agnați (agnatus proximus), în baza a ceea ce ulterior s-a numit principiului chemării la moștenire în ordinea claselor de moștenitori.99 Un alt neajuns imputat

\footnotetext{
${ }^{98}$ Inst. 3.3.pr. „Lex duodecim tabularum ita stricto iure utebatur et praeponebat masculorum progeniem, et eos qui per feminini sexus necessitudinem sibi iunguntur adeo expellebat, ut ne quidem inter matrem et filium filiamve ultro citroque hereditatis capiendae ius daret, nisi quod praetores ex proximitate cognatorum eas personas ad successionem bonorum possessione unde cognati accommodata vocabant.” („Legea celor XII table a aplicat atât de strict principiul preferinței succesiunii prin bărbați, cu excluderea succesiunii prin femei, încât nu a admis un drept de moștenire reciproc între mamă și copiii acesteia. Totuşi, pretorii le-au îngăduit să succeadă unii altora în clasa cognaților.”) Vladimir HANGA, Mircea Dan BoB, Instituțiile lui Iustinian, ed. Universul Juridic, București, 2009, p. 247. Desigur, inechitatea instituită de dreptul civil și dreptul pretorian este surmontată de posibilitățile largi ale lui pater familias de a dispune de bunuri în favoarea soțului supraviețuitor. Însă, interesul cercetării este determinarea drepturilor succesorale ale soțului în lipsa unei manifestări de ultimă voință a lui de cuius.

99 Acest principiu se regăsește în textele Instituțiilor lui Gaius, în materia succesiunii legale: Gaius III.9, respectiv Gaius III.17.
} 
succesiunii pretoriene a constat în soluționarea conflictului dintre drepturile moștenitorului civil și ale celui pretorian în favoarea primului. ${ }^{100}$

Dreptul imperial vine în completarea activității reformatoare începută de pretor, cu intenția de a corija unele (sau chiar toate) dintre aceste nedreptăţi.

În perioada Principatului, Senatus-consultele Tertullian ${ }^{101}$ şi Orfitian $^{102}$ au extins sfera rudele de sânge chemate la moștenire, stabilind un

${ }^{100}$ Inst. 3.9.2. „Quos autem praetor solus vocat ad hereditatem, heredes quidem ipso iure non fiunt (nam praetor heredem facere non potest: per legem enim tantum vel similem iuris constitutionem heredes fiunt, veluti per senatus consultum et constitutiones principales: sed cum eis praetor dat bonorum possessionem, loco heredum constituuntur et vocantur bonorum possessores. adhuc autem et alios complures gradus praetor fecit in bonorum possessionibus dandis, dum id agebat, ne quis sine successore moriatur: nam angustissimis finibus constitutum per legem duodecim tabularum ius percipiendarum hereditatum praetor ex bono et aequo dilatavit." (Când pretorul cheamă la succesiune persoane care nu au acest drept după dreptul civil, ele nu devin moștenitori de plin drept, căci pretorul nu poate face un moștenitor; numai printr-o lege sau printr-o hotărâre ce are forță de lege, de pildă, un senatusconsult sau o constituție imperială, se poate dobândi calitatea de erede. Deoarece însă pretorul le acordă o posesiune de bunuri, asemenea persoane sunt situate în poziția de moștenitori și se numesc „posesori de bunuri”. Pretorul a creat mai multe grade de moștenire, acordând „posesiunea de bunuri” în intenția ca nimeni să nu moară fără un moștenitor. De aceea el a extins, în temeiul unui principiu de echitate, dreptul de a dobândi o moștenire dincolo de limitele inechitabile ale legii celor XII table.) Vladimir HANGA, Mircea Dan BoB, op.cit., p. 267; Mircea Dan Boв, op.cit., p. 323.

101 Acesta a fost adoptat pe timpul domniei împăratului Publius Aelius Hadrian (117-138 p. Chr.). Prin implementarea hotărârii Senatului, mama a fost chemată, în calitate de moștenitor civil, la succesiunea copiilor săi, înaintea tuturor agnaților. Inst. 3.3.2.; Jean-Philippe LEVY, Andre CASTALDO, op.cit., p. 1145; Dan OANCEA, op.cit., p. 168; Thomas RÜFNER, op.cit., p. 1820.

${ }^{102}$ Senatus-consultul a fost adoptat în timpul domniei lui Marcus Aurelius Antoninus (161-180 p. Chr.). Astfel, la decesul mamei, descendenții săi au dobândit un rang prioritar agnaților care, în calitate de legitimi, ar fi avut întâietate în cadrul ordinii succesorale instituită de bonorum possessio. Inst. 3.4.pr.; Jean-Philippe LEVY, Andre CASTALDO, op.cit., p. 1146. De asemenea, alături de copiii legitimi, rezultați din căsătorie sunt chemați la succesiunea mamei și cei naturali sau nelegitimi. Inst. 3.4.3; Thomas RÜFNER, op.cit., p. 20-21.

\section{1}


drept reciproc de moștenire între mamă și copiii săi. ${ }^{103}$ Alături de aceste hotărâri ale Senatului, au fost adoptate mai multe constituții imperiale. ${ }^{104}$

În continuarea reformei pretoriene de lărgire a vocației succesorale a moștenitorilor legali, urmată de senatus-consultele amintite şi de constituțiile imperiale subsecvente, împăratul Iustinian a pus capăt distincției dintre moştenitorii civili și cei pretorieni și a construit bazele solide ale unui sistem succesoral întemeiat exclusiv pe rudenia de sânge. ${ }^{105}$

În dreptul roman postclasic, prin Novelele 118 (din anul 544 p. Chr.) şi 127 (din anul 548 p. Chr.), Iustinian a introdus următoarele clasele de moștenitori: descendenții, ascendenții şi colateralii lui de cuius, toți aceștia fiind persoane aflate într-o legătură cognatică cu defunctul.106 În privința soțului supraviețuitor, Novela $118 \mathrm{nu}$ a operat o modificare a dispozițiilor prevăzute de bonorum possessio, iar tăcerea acestuia a fost interpretată în sensul că dreptul postclasic a preluat concepția pretoriană în ceea ce-l privește pe soțul supraviețuitor. ${ }^{107}$ Așadar, acesta se situează la finele devoluțiunii legale, venind la moștenire numai în absența oricărui alt moștenitor cu vocație

\footnotetext{
${ }^{103}$ Mircea Dan BOB, op.cit., p. 323; Vladimir HANGA, op.cit., p. 318.

${ }^{104}$ Pentru detalii, a se vedea Mircea Dan Bob, op.cit., p. 323; Vladimir HaNGA, op.cit., p. 318; Valerius M. CIUCĂ, op.cit., p. 757-758.

105 Jean-Philippe LEVY, Andre CASTALDO, op.cit., p. 1146.

${ }^{106} \mathrm{Cu}$ privire la numărul claselor de moștenitori, unii autori afirmă că acestea ar fi în număr de trei (Valerius M. CIUCĂ, op.cit., p. 758; Jean-Philippe LEVY, Andre CASTALDO, op.cit., p. 1146), iar alții susțin că Iustinian a instituit, de fapt, patru clase (Vladimir HANGA, op.cit., p. 318-319; Dan OANCEA, op.cit., p. 169; Emil MolCUȚ, op.cit., p. 153; Thomas RÜFNER, op.cit., p. 26-27). Indiferent de numărul efectiv al claselor de moștenitori, acești autori convin asupra tuturor persoanelor care au vocație efectivă la succesiunea defunctului, fapt ce lipsește de importanță practică disputa menționată.
}

${ }^{107}$ Dan OANCEA, op.cit., p. 170. 
concretă și doar înaintea statului. ${ }^{108}$ Alți autori sunt de părere că soțul supraviețuitor este inclus în cea de-a patra clasă de moștenitori (utilizând, desigur, împărțirea tripartită a moștenitorilor legali), intitulată „clasă neregulată sau ordin neregulat de drept pretorian”. ${ }^{109}$ Oriunde l-am poziționa pe soțul supraviețuitor, şansele ca acesta să culeagă bunuri din masa succesorală erau extrem de reduse. ${ }^{110}$ De aceea s-a reținut că „este o inechitate strigătoare la cer” chemarea la moștenire a soțului supraviețuitor abia după colateralii ordinari. ${ }^{111}$

Cum am putea justifica dispozițiile adoptate de Iustinian în materia devoluțiunii $a b$ intestato a soțului supraviețuitor? Decizia de politică legislativă a avut rădăcini în realitatea socială a vremii sau a fost impusă în mod unilateral de către împărat?

În perioada imperială, ginta dispare în totalitate. ${ }^{112}$ În consecință, apartenența la gintă nu mai constituie un element component al dreptului succesoral ${ }^{113}$ sau al instituției tutelei. ${ }^{114}$

\footnotetext{
${ }^{108}$ Mircea Dan Bob, op.cit., p. 323; Vladimir HangA, op.cit., p. 319. Dreptul statului de a culege o moștenire vacantă a apărut în dreptul grecesc. În drept roman a fost instituit prin legile Iulia et Papia Poppaea. Conform unei opinii pe care o împărtășim, statul nu culege moștenire în calitate de succesor cu vocație legală, ci în virtutea dreptului de suveranitate. Jean-Philippe LEVY, Andre CASTALDO, op.cit., p. 1146-1147.

${ }^{109}$ Valerius M. CIUCĂ, op.cit., p. 764.

${ }^{110}$ Fapt, de altfel, recunoscut de Iustinian în preambulul capitolului VI din Novela 53.

${ }^{111}$ Valerius M. CIUCĂ, op.cit., p. 764.

112 Jacques ELLUL, op.cit., p. 490.

113 „La structure du groupe familial conditionne le régime légal des successions, où les éléments gentilices gardent leur importance" Mario BRETONE, Histoire du droit romain, ed. Delga, Paris, 2015, p. 94.

114 Jacques ElLUL, op.cit., p. 490.
} 
Începând cu reforma pretorului și continuând cu modificările din dreptul postclasic, drepturile succesorale ale membrilor ginții s-au diminuat treptat, până la dispariție.

Odată cu instaurarea Dominatului, reglementările în materie de tutor mulieris au suferit modificări care au condus, în final, la dispariția acestei instituții. Astfel, începând cu anul 390 p. Chr., văduvelor le era îngăduit să fie tutorele copiilor sau ale nepoților, cu condiția de a nu se recăsători. ${ }^{15}$ În anul $530 \mathrm{p}$. Chr. Iustinian a extins dreptul femeilor de a fi tutorele copiilor și mamelor biologice. ${ }^{116}$

Modificările survenite în construcția familiei romane au condus, începând cu secolul al IV-lea p. Chr, la inevitabila căderea în desuetudine a instituției tutelei femeii ${ }^{117}$ care dispare în baza unei constituții imperiale a împăratului Constantin. ${ }^{118}$

Importanța practică a eliminării tutelei femeii constă în consacrarea deplină a dependenței patrimoniale a acesteia, prin recunoaşterea nestingherită a atributului de dispoziție asupra bunurilor proprii. ${ }^{119}$

Societatea romană imperială era constituită din două clase: cea bogată și care deținea toată puterea și cea săracă. ${ }^{120}$ Cele două erau separate prin bariere sociale, economice, juridice și politice. ${ }^{121}$ Din perspectivă socială, s-a

\footnotetext{
115 Eva CANTARELLA, op.cit., p. 425-426.

${ }^{116}$ Idem, p. 426.

${ }^{117}$ Pentru detalii, a se vedea Cristina Pop, Divorțul și succesiunile. Instrumente juridice de emancipare a femeï în societatea romană, ed. Universul Juridic, București, 2018.

${ }^{118}$ C. 2.44.2.1. Verena HaLBWACHS, op.cit., p. 449.

119 Din perspectivă creștină, totuși femeia rămâne inferioară bărbatului. Sfânta Scriptură (ortodoxă), Efeseni 5, 22-23, ed. Institutului Biblic și de Misiune Ortodoxă, București, 1975, p. 1315 .

${ }^{120}$ Jacques ELLUL, op.cit., p. 572.

${ }^{121}$ Ibidem.
} 
afirmat că cea mai stringentă problemă o reprezentau marii proprietari (latifundium).122 Aceștia refuzau să plătească impozite, interzicându-le decurionilor să-și îndeplinească atribuțiile. De asemenea, marii proprietari au construit un sistem propriu de apărare militară a proprietății, capele creștine și închisori private, având autonomie față de stat impusă unilateral. Astfel, teritoriul deținut de aceștia era practic în afara jurisdicției statale. ${ }^{123}$

Preocupat de menținerea aceluiași nivel de trai și rang social din timpul căsătoriei, în contextul social al secolului al V-lea și al VI-lea p.Chr., Iustinian a considerat oportună ajustarea drepturilor succesorale ale soțului supraviețuitor. Demersul s-a realizat în două etape, respectiv prin Novela 53 (din anul 537 p. Chr.) și prin Novela 117 (din anul 543 p. Chr.).

Dispozițiile capitolului VI al Novelei $53^{124}$ acordă soțului supraviețuitor un drept reciproc de moștenire (similiter quidem in viris, similiter autem in mulieribus) în situația în care a contractat o căsătorie legitimă în lipsă de zestre sau nebeneficiind de o donație ante nuptias. ${ }^{125}$ Acest

\footnotetext{
122 Ibidem.

${ }^{123}$ Prin măsuri legislative, s-a încercat diminuare acestor puteri, însă fără a avea o finalitate practică. Pentru detalii, a se vedea idem, p. 572-573.

${ }^{124}$ Anterior adoptării Novelei 53, Iustinian a acordat dreptul soției căsătorită fără dotă la o pătrime în proprietate din bunurile soțului în situația în care aceasta a fost repudiată fără drept (capitolul XVIII, Novela 22, elaborată în anul 535 p.Chr.). Este interesant de remarcat, din perspectiva noastră, faptul că dacă din căsătoria celor doi au rezultat copii, intervenea o schimbare în natura dreptului dobândit: „soțul nu primea proprietatea sfertul de cât cu condițiunea de a o păstra și de a o lăsa la moartea sa”. GR. C. CONDURATU, op.cit., p. 22., iar nu în ceea ce privește întinderea acestuia. Prin urmare, mama copiilor repudiată fără drept avea, în realitate, un drept de uzufruct asupra pătrimii respective. Observăm că simțul juridic al împăratului, dirijat de dorința de a echilibra balanța patrimonială conjugală, s-a resimțit, mai întâi, în planul intereselor economice ale femeii în viață, asigurându-se totodată că nudaproprietate rămâne familiei de sânge. Mai apoi, la numai doi ani distanță, s-a reglementat situația soților, după decesul partenerului de viață.

125 Este vorba despre un veritabil douaire, care a apărut mai târziu. Soțul administrează bunurile, cât timp trăiește, urmând ca la decesul său, acestea să treacă la văduvă. Jean-Philippe
} 
drept consta într-o pătrime în plină proprietate din masa succesorală, indiferent de numărul descendenților cu care venea în concurs. De asemenea, pentru ca dreptul de moștenire să se nască era necesar ca defunctul să fi fost bogat, iar cel care supraviețuiește sărac ${ }^{126}$ (ut moriens locuples inveniatur superstes autem pauper existat).127 Situația financiară a soților era o chestiune de fapt, lăsată „din nenorocire la aprecierea judecătorului”. ${ }^{128}$

În literatură, s-a ridicat următoarea întrebare: existenței unei zestre de o valoare neînsemnată înlătură $a b$ initio quarta soției? ${ }^{129}$ Din perspectiva noastră, condiția lipsei resurselor financiare este fundamentul acordării acestui drept succesoral, iar nu existența sau inexistența bunurilor dotale ori a acelora obținute dintr-o donație ante nuptias. Desigur, puterea de apreciere a judecătorilor este direct proporțională cu valoarea zestrei ori a donației.

LEVY, Andre CASTALDO, op.cit., p. 1536. Începând cu anul 382 p. Chr., la decesul soțului, soția supraviețuitoare recăsătorită dobândește bunurile care formează obiectul donației ante nuptias numai în uzufruct, nuda-proprietate revenind descendenților rezultați din căsătoria cu defunctul. Jacques ElLuL, op.cit., p. 579. Iată aşadar, un alt caz în care soția dobândește un drept de uzufruct, în concurs cu moștenitorii din clasa întâi.

${ }^{126}$ Deținerea unor bunuri importante în patrimoniul determină neîndeplinirea acestei condiții. George DUMiTRIU, op.cit., p. 82.

${ }^{127}$ Durata căsătoriei nu constituie o condiție esențială în vederea acordării acestui drept. Au fost exprimate şi opinii contrare. Pentru o expunere a acestora, a se vedea Cristina PoP, $O$ privire de ansamblu asupra inovațiilor legislative ale împăratului Uxorius, SUBB Iurisprudentia, nr. 2/2016, p. 62.

${ }^{128}$ Nicolae AleXANDRescu, Condițiunea succesorală a femeii în dreptul roman, francez şi român, ed. Lito-tipografia Ion S. Codreanu, București, 1898, p. 23.

${ }^{129} \mathrm{~S}$-au exprimat, şi sub acest aspect, opinii divergente. Pentru detalii, a se vedea J. CuJAS, Recitationes solemnes ad lib. VI Codicis, Unde vir et uxor, ed. Fabrot, col. 630, 1781 şi R. J. PothIER, Pandecte de Justinien, Paris, 1822, p. 480 apud George Dumitriu, op. cit., p. 60. 
Inexistența acestor acte este o simplă prezumție relativă a stării de sărăcie a soției supraviețuitoare, nicidecum o condiție eliminatorie. ${ }^{130}$

Aplicând dispozițiile dreptului imperial, care este situația juridică și patrimonială a fiecăruia dintre soți declanşată de decesul femeii, respectiv al bărbatului? Le vom analiza pe rând.

În esență, la decesul soției, soțul supraviețuitor înapoia bunurile dotale $^{131}$ descendenților femeii, moștenitori de rang întâi (capitolul I, Novela 118). În devoluțiunea $a b$ intestato, soțul se poziționează în ultima clasă, venind la moștenire numai în absența tuturor rudelor de sânge, până la gradul al şaptelea, inclusiv.132 In virtutea dispozițiilor Novelei 53 şi sub rezerva întrunirii tuturor condițiilor, acesta poate beneficia de quarta soțului sărac. Pe lângă acest drepturi directe, soțul beneficia de un uzufruct asupra bunurilor cuprinse în bona materna ${ }^{133}$ dobândite în nudă-proprietate de către descendenții femeii, dacă aceștia se aflau sub patria potestas a soțului. ${ }^{134}$ Chiar dacă toți descendenții erau emancipați, soțul supraviețuitor dobândește uzufructul unei treimi din bona materna, iar nuda-proprietate era păstrată de

\footnotetext{
${ }^{130}$ În situația în care defunctul testează în favoarea soției, atribuindu-i o cotă inferioară quartei, soția va beneficia de întregirea dreptului său până la complinirea pătrimii în plină proprietate (desigur, sub rezerva întrunirii celorlalte condiții). Cristina PoP, op.cit., p. 61.

${ }^{131}$ Este posibil ca spre sfârșitul imperiului, să fi existat obligația părinților de a constitui o dotă la căsătoria fiicei lor. D. 23.2.19. Chiar și în lipsa unei obligații efective, este evident că părinților le incumba o obligație morală de a-şi dota fiica. J. L. BARTON, op.cit., p. 14.

${ }^{132}$ Jean-Philippe LEvy, Andre CASTALDO, op.cit., p. 1537.

${ }^{133}$ Inițial din bona materna făcea parte numai bunurile dobândite pe temei succesoral de la mama copiilor. Ulterior, regimul bona materna se aplica tuturor bunurilor deținute de descendenți și care provin din alte surse decât de la pater familias. Thomas RüFNER, op.cit., p. 23.

${ }^{134}$ Thomas RÜFNER, op.cit., p. 23. Temeiul juridic în virtutea căruia cognații vin la moștenirea mamei lor se regăsește în dispozițiile senatus-consultului Orfitianum.
} 
moştenitorii emancipați din clasa întâi. ${ }^{135}$ Observăm așadar, că bărbatul dobândea drepturi din succesiunea soției atât în mod direct, cât și indirect, beneficiind de folosința bunurilor acesteia, în calitate de titular al unui drept de uzufruct. ${ }^{136}$

Din perspectiva dreptului succesoral, situația soției supraviețuitoare era mai avantajoasă, atât faţă de drepturile sale din perioada clasică, cât şi față de drepturile soțului din epoca imperială, ${ }^{137}$ insă nu beneficia de o poziție atât de favorabilă ca în vechiul drept roman. Aceasta dobândea bunurile dotale ${ }^{138}$ şi cele care au format obiectul donației propter nuptias. ${ }^{139}$ Obținea astfel la moartea soțului dublul bunurilor dotale (ca dotă şi ca donație), în plină proprietate, în dauna moştenitorilor soțului. ${ }^{140}$ În lipsa totală a zestrei sau a donaţiei ante nuptias, ori în ipoteza unui cuantum scăzut al acestora, cu condiția întrunirii condițiilor cerute de Novela 53, soția avea aptitudinea de a obține pătrimea soțului sărac în plină proprietate. În cadrul devoluțiunii $a b$ intestato, soția se află pe aceeaşi poziție dezavantajoasă.

\footnotetext{
${ }^{135}$ C. 6, 6o, 3 pr.

136 Pater familias păstrează dreptul de uzufruct asupra bona materna și la decesul descendenților aflați sub puterea acestuia, iar numai nuda-proprietate va reveni moștenitorilor acestora din urmă. Nov. 118, 1. Thomas RüFNER, op.cit., p. 27.

137 Problema bigamiei, prin venirea a doi soți la succesiune nu ridică dificultăți, întrucât încheierea unei căsătorii subsecvente, o dizolva ipso facto pe cea veche. Jacques ElLUL, op.cit., p. 578 .

138 În concluzie, acordarea unui drept succesoral văduvei sărace (mulier inops et indotata) a avut la bază îngrijorarea împăratului Iustinian pentru situația patrimonială a soțului supraviețuitor, cu precădere în cazul în care în poziția acestuia se afla o femeie, fundament distinct de cel avut în vedere la implementarea exclusivă a cognațiunii în devoluțiunea legală și anume, afecțiunea prezumată a defunctului față de rudele de sânge ale sale. Considerăm că rațiunea rezidă în modul de percepere al instituției căsătoriei în acea perioadă, precum și în concepția predominantă a caracterului alogen al soțului. Jean-Philippe LEVY, Andre CASTALDO, op.cit., p. 1450-1451.

${ }^{139}$ Jean-Philippe LEVY, Andre CASTALDO, op.cit., p. 1537.

${ }^{140}$ Ibidem.
} 
Preocuparea pentru situația soțului supraviețuitor pare a deveni constantă când, la numai șase ani de la elaborarea Novelei 53, Iustinian adoptă Novela 117. Aceasta acoperă situația soției din două perspective: în cazul în care femeia nevoiaşă era repudiată sine causa de către soțul său și ipoteza în care soția supraviețuitoare era săracă. În primul caz, soția dobândea o pătrime în plină proprietate, iar în cel de-al doilea caz, natura dreptului şi întinderea lui depindeau de mai multe elemente, precum: numărul și calitatea descendenților, respectiv valoarea masei succesorale.

Potrivit regimului juridic reglementat de Novela 53, dreptul soției supraviețuitoare nu era influențat de alți moștenitori cu care aceasta venea în concurs. Dispozițiile Novelei 117 operau o distincție fundamentală între situația în care, alături de soția supraviețuitoare se găsesc și copii rezultați din căsătorie, caz în care aceasta va beneficia de un drept de uzufruct ${ }^{141}$ și lipsa acestora, când dreptul dobândit va fi în plină proprietate. ${ }^{142}$

Reciprocitatea dreptului soțului sărac este înlăturată de Iustinian prin Novela 117. Începând cu anul 543 p. Chr., numai soția săracă putea beneficia de o pătrime sau de o parte virilă din succesiunea defunctului, în plină proprietate sau în uzufruct, după caz. ${ }^{143}$

Limitarea cuantumului dreptului soției la 100 de livre de aur a fost stipulat pentru prima dată în Novela 22, capitolului XVIII și reiterată de

\footnotetext{
141 Nov. 117, 5. Nuda proprietate revenind copiilor quos ex ipsis nuptiis habuit. GR. C. CONDURATU, op.cit., p. 73 .

142 Jean-Philippe LEvy, Andre CASTALDO, op.cit., p. 1148.

143 De asemenea, senatus-consultele Tertullian și Orfitian nu consacră, individual, drepturi reciproce între mamă şi copiii săi. Novela 53 a fost sigura care a adoptat reciprocitatea drepturilor de moștenire ale soților. Pentru discuții doctrinare cu privire la rațiunea care l-a determinat pe Iustinian să mențină dreptul numai în favoarea soției, a se vedea George DUMITRIU, op.cit., p. 75-78. Acest autor este de părere că se impunea acordarea reciprocă a dreptului de moștenire. Idem, p. 78.
} 
Novela 117. Astfel, soția supraviețuitoare, nu va putea beneficia de un drept de moștenire care depășește această valoare, chiar dacă masa succesorală a soțului său ar fi permis acest lucru.

O altă restricție prevăzută de Novela 117 constă în reducerea întinderii acestui drept la o porțiune virilă, în situația în care soțul supraviețuitor vine în concurs cu mai mulți de trei copii legitimi, pentru a nu dezavantaja descendenții în favoarea soției sărace.

Dreptul imperial, în special legislația lui Iustinian, a consacrat pentru prima dată diferențierea naturii şi întinderii drepturilor succesorale ale soției sărace în funcție de anumite criterii printre care: numărul și calitatea descendenților.

Credem că opțiunea împăratului Uxorius pentru acest tratament diferențiat se justifică prin dorința de a oferi soției supraviețuitoare cele necesare traiului, dar în acelaşi timp de a conserva (cel puțin) nudaproprietate în familia de sânge a defunctului. Iustinian s-a bazat pe posibilitatea scăzută ca descendenții născuți din căsătorie să cauzeze inconveniente ascendentului biologic care are un drept de uzufruct viager. În ipoteza în care soția săracă nu este cognată cu ceilalți moștenitori, atunci opțiunea împăratului s-a îndreptat către dreptul de proprietate, punând-o pe femeie la adăpost de eventualele neînțelegeri ori posibile abuzuri din partea rudelor de sânge ale defunctului.

Observăm, așadar, că Iustinian s-a îngrijit să ofere o soluție echitabilă atât din perspectiva naturii dreptului, cât și a cuantumului acestuia, stabilind criterii clare și precise în acest sens. Mărturie prezentei concluzii stă și 
utilizarea legislației lui Iustinian ca sursă de inspirație pentru majoritatea sistemelor de drept continentale. ${ }^{144}$

\section{Scurte concluzii}

Problema juridica asupra căreia ne-am aplecat în acest studiu a fost centrată în jurul evoluției istorice a drepturilor succesorale ale soțului supraviețuitor.

În urma cercetărilor efectuate, am constatat că vocaţia succesorală a soțului supraviețuitor, precum și întinderea drepturilor sale patrimoniale rezultate din devoluțiune legală a suferit modificări de-a lungul timpului, fiind influențată de viziunea societăţii romane asupra conceptului de familie, de formele de căsătorie și, nu în ultimul rând, de regimul matrimonial aplicabil soților.

Pe același șablon, ne propunem să analizăm dispozițiile din vechiul drept românesc scris în vigoare în Vechiul Regat.

\footnotetext{
${ }^{144} \mathrm{Cu}$ titlu de exemplu, este vorba despre sistemul juridic din Franța, unde modelul instituit de Novela 118 a fost urmat de pays de droit écrit, Spania (Siete Partidas), România (vechiul drept cutumiar) etc.
} 